\title{
Silurian and Lower Emsian spores in Saudi Arabia
}

\author{
P. Steemans \\ N.F.S.R. Research Associated, Services associés de Paléontologie de l'Université de Liège, 7, Pl. du XX Août, \\ Université de Liège, B-4000 Liège, Belgium
}

Received 11 June 1993; revised and accepted 17 August 1994

\begin{abstract}
Silurian cryptospores and Silurian to Lower Devonian miospores are identified in cuttings from three wells situated in Saudi Arabia between longitudes 42 and $51^{\circ} \mathrm{E}$ and latitudes 23 and $29^{\circ} \mathrm{N}$. All samples are contaminated by caved younger spores and pollen. The biostratigraphic scheme defined in western Europe is tentatively applied. The identical succession of first occurences of the key-species approximately dates the levels sampled. A discordance is demonstrated between the Silurian and the Lower Devonian deposits in each examined well. The ages of the first Lower Devonian sediments in these wells suggest a transgressive direction from SE to NW. Two new taxa are formally introduced: Cymbosporites dammanensis Steemans, $s p$. nov. and Chelinospora arabiensis Steemans, sp. nov.
\end{abstract}

\section{Introduction}

Cutting samples obtained from three Saudi Arabian wells ranging from longitudes 42 to $51^{\circ} \mathrm{E}$ and from latitudes 23 to $29^{\circ} \mathrm{N}$ have been palynologically examined. These three wells, TRBH-1, DMMM-45 and UDYN-1 (Fig. 1), penetrated presumed Silurian and Lower Devonian strata. The samples described here have been obtained from these strata.

The study has been extensively complicated by abundant contaminations, clearly demonstrated by the occurence of post-Lower Devonian material. The composition of the spore assemblages in the samples is uncertain because of poor preservation.

These boreholes are not suitable to construct a local biostratigraphic zonal scale because of the extensive contamination. We have, therefore, applied the existing biozonations of Richardson and McGregor (1986), Streel et al. (1987), Richardson (1988), and Steemans (1989).

It is assumed that the key-species of the biozone found in the cutting samples occur in the same succession as in the Ardenno-Rhenish type sections, that this succession is not affected by contamination, and that the biozone limits are close to the depth of the examined intervals.

\section{Stratigraphic palynology}

\subsection{Well DMMM-45}

Seventeen cutting samples between 13120 and $12500 \mathrm{ft}$ have been examined from well DMMM-45 (Fig. 1). The intervals $13100-13120 \mathrm{ft}, 12920-$ $12940 \mathrm{ft}$ and $12770-12790 \mathrm{ft}$ are barren. The Devonian section is separated from the underlying Silurian Qalibah Formation by a discordance in the interval $13100-13220 \mathrm{ft}$. Fig. 2 shows the most important spore species identified.

The intervals $13110-13120 \mathrm{ft}$ and $13100-13110$ $\mathrm{ft}$ from the upper part of the Sharawra member of the Qalibah Formation yielded very few specimens. No biostratigraphically significant species have been identified apart from Synorisporites 


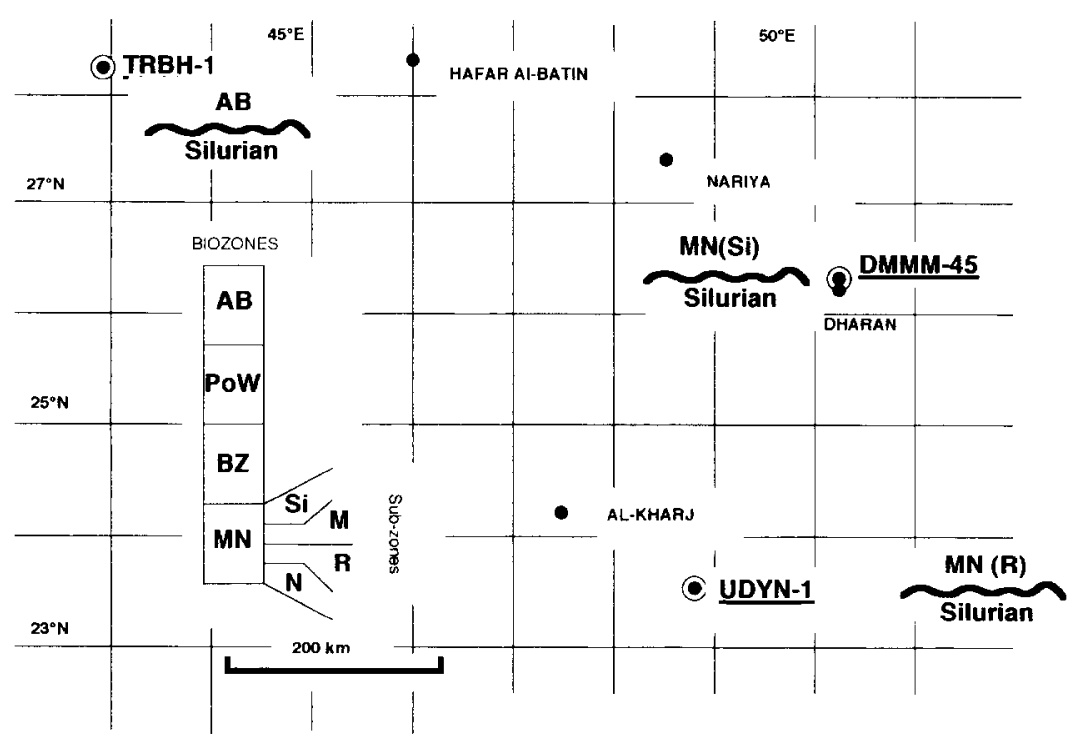

Fig. 1. Location of wells and the unconformity between the Silurian and the Devonian.

verrucatus, ranging from the Silurian into the Lochkovian (Steemans, 1989).

The assemblage in the interval $13090-13110 \mathrm{ft}$ contains a greater number of palynomorphs, but only one index species has been found: Tetrahedraletes medinensis which, together with Emphanisporites neglectus and Synorisporites verrucatus, could probably indicate a Wenlock-Ludlow age (Burgess and Richardson, 1991). The presence of Apiculiretusispora pygmaea is probably due to caving.

The interval 12940-13000 ft from the lower part of the Tawil Formation is assumed to be of Lochkovian age because of the presence of Chelinospora retorrida, Emphanisporites novelus, and a poorly preserved specimen related possibly to ?Emphanisporites micrornatus var. sinuosus. These species are characteristic of the Lochkovian $\mathrm{MN}$ Assemblage Biozone. The presence of Cymbosporites multiconus and ?E. micrornatus var. sinuosus, probably indicates middle Lochkovian Phylozone Si (for the biostratigraphic scale, see Streel et al., 1987; Steemans, 1989).

Perotrilites reticulatus has been observed in the interval $12900-12940 \mathrm{ft}$, together with nonstratigraphically diagnostic taxa. This species is only known in Belgium from Biozones $\mathrm{Si}$ to $\mathrm{Z}$
Phylozones (being rare in the latter), and is considered as reworked in the Pragian Biozone Su (Steemans, 1989). The interval $12900-12940 \mathrm{ft}$ is therefore believed to range from the Lochkovian $\mathrm{Si}$ to $\mathrm{Z}$ Biozones. A new species, Cymbosporites dammamensis (see section on taxonomy below) is observed in the interval 12540-12550 ft.

Species obtained from the interval 12880-12890 $\mathrm{ft}$ are characteristic of the $\mathrm{BZ}$ Assemblage Biozone, and more particularly of the $\mathrm{E}$ Interval Biozone. Aneurospora bollandensis, Emphanisporites novellus, Amicosporites streelii, and Dibolisporites sp. E (in Steemans, 1989) have been identified. The E Interval Biozone spans the Lochkovian Pragian boundary.

Dibolisporites wetteldorfensis, the index species for the W Interval Biozone in the PoW Assemblage Biozone, has been observed in the intervals $12770-12780 \mathrm{ft}, 12590-12640 \mathrm{ft}$ and $12550-12560$ $\mathrm{ft}$ of the upper Tawil Formation. The following main taxa have been identified from the interval 12770-12780 ft: Amicosporites splendidus, Apiculiretusispora pygmaea, Cymbosporites dammamensis, and Dibolisporites wetteldorfensis. The following have been recorded from the interval 12550-12560 ft: Apiculiretusispora pygmaea, Dictyotriletes emsiensis, Cirratriradites diaphanus, 


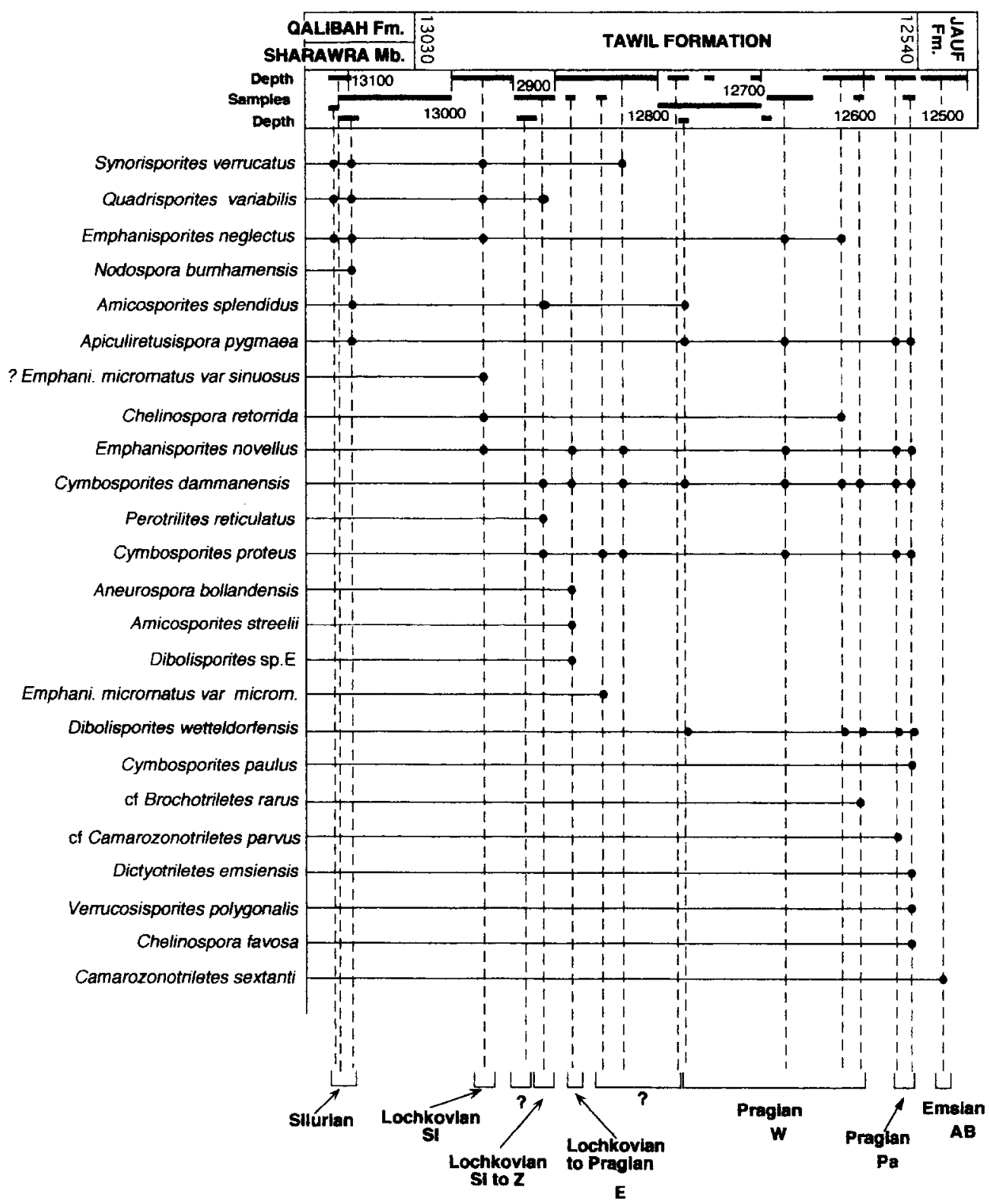

Fig. 2. Stratigraphic distributions of some selected spores in well DMMM-45.

Chelinospora favosa, and Verrucosisporites polygonalis. The latter together with Dibolisporites wetteldorfensis allows the assignment of these two horizons to the Pragian W Biozone.

The possible occurrence of Camarozonotriletes parvus indicates a Pragian age ( $\mathrm{Pa}$ Interval Biozone) for the intervals $12540-12580 \mathrm{ft}$ and
$12550-12560 \mathrm{ft}$. The biostratigraphic boundary, therefore, occurs between 12540 and $12550 \mathrm{ft}$ as indicated by the results obtained from the preceding interval. Dibolisporites wetteldorfensis and Cymbosporites dammamensis are still recognised in these horizons.

The occurrence of Camarozonotriletes sextanti 
in the interval $12520-12540 \mathrm{ft}$ of the Jauf Formation suggests that at least the $\mathrm{AB}$ Assemblage Biozone (Early Emsian) has been penetrated Streel et al., 1991).

\subsection{Well $U D Y N-1$}

Ten samples have been examined. They were obtained from the interval $14460-15320 \mathrm{ft}$. The interval between 14920 and $14930 \mathrm{ft}$ was found to be barren. The Devonian is unconformable with the underlying Silurian Qalibah Formation at an estimated depth of $15358 \mathrm{ft}$. The succession of the most important identified taxa in these samples is shown in Fig. 3.

The interval $15320-15360 \mathrm{ft}$ from the upper part of the Sharawra member and the lowermost part of the Tawil Formation contains only very few palynomorphs. Trilete spores and cryptospores (Richardson et al., 1984) have been identified. Amongst the cryptospores are Tetrahedraletes medinensis, Dyadospora murusdensa, and Laevolancis divellomedium. Trilete miospores are somewhat more numerous and the following species have been identified: Ambitisporites dilutus, $A$. avitus, Trilete miospore type 1 (in Burgess and Richardson, 1991), cf. ?Lophozonotriletes poecilomorphus, Emphanisporites neglectus, Amicosporites splendidus, Synorisporites verrucatus. The incertae sedis Hoegisphaera sp. A (in Gao and Ye, 1987) has also been identified.

The overlying interval $15290-15300 \mathrm{ft}$ in the Tawil Formation also contains mixed trilete spores and cryptospores. In addition to the cryptospores mentioned in the first sample, Quadrisporites variabilis, Segestrespora membranifera and Hilate cryptospore type 1 (in Burgess and Richardson, 1991) have been recognised. Only two trilete spore species were found: Ambitisporites dilutus and Synorisporites verrucatus.

These two intervals can be considered together since they are characterised by the occurrence of cryptospores which are absent elsewhere in the well. On the other hand, the same trilete spores are found both in these two intervals and in higher parts of the well. It is therefore not possible to decide whether these trilete spores and cryp- tospores are really contemporaneous. Segestrespora membranifera is known only from the $S$. membranifera-Segestrespora $\mathrm{sp}$. B Biozone (Richardson, 1988). Some other species, such as T. medinensis and D. murusdensa, may be contemporaneous with $S$. membranifera. This biozone ranges from the upper part of Ashgill to the early Aeronian (Richardson, 1988; Burgess, 1991; Steemans, unpubl. data). A. avitus and $A$. dilutus appear in the overlying biozone of which they are the index species. They are still present in the Lower Devonian. S. verrucatus and Hilate cryptospore type 1 (in Burgess and Richardson, 1991) appear in the immediately younger cf. protophanus-verrucatus biozone. This biozone was described for the first time by Richardson and McGregor (1986) and revised by Burgess and Richardson (1991). In Great Britain, it extends from Upper Wenlock to the Lower Ludlow (Homerian-Gorstian). ?L. poecilomorphus is characteristic of the overlying biozone (libycuspoecilomorphus). Nevertheless, Richardson and McGregor (1986, fig. 3) indicated this species as being already present, together with E. neglectus, in the cf. protophanus-verrucatus biozone.

The occurrence of $S$. membranifera at $15300 \mathrm{ft}$ indicates an Ashgillian or Lower Silurian age for the interval $15290-15300 \mathrm{ft}$. Synorisporites verrucatus and Hilate cryptospore type 1 (in Burgess and Richardson, 1991) indicate that Wenlock or even Ludlow strata must exist between 15300 and 15260 $\mathrm{ft}$ (where the Lower Devonian is penetrated).

The spore assemblage of the intervals 15220 $15260 \mathrm{ft}, 15170-15210 \mathrm{ft}, 15120-15170 \mathrm{ft}$ and $15070-15120 \mathrm{ft}$ have been considered together. The interval $15220-15260$ contains, among others, Cymbosporites proteus, C. paulus and Chelinospora retorrida. These species appear in the Streelispora newportensis-Emphanisporites micrornatus var. micrornatus Assemblage Biozone (MN Assemblage Biozone in Steemans, 1989) (Richardson and McGregor, 1986; Steemans, 1989; Streel et al., 1987). The occurrence of $C$. retorrida indicates that the R Interval Biozone has been penetrated. The first occurrence of a new spore species from that interval is of importance: Chelinospora arabiensis Steemans, sp. nov. (see section on taxonomy 


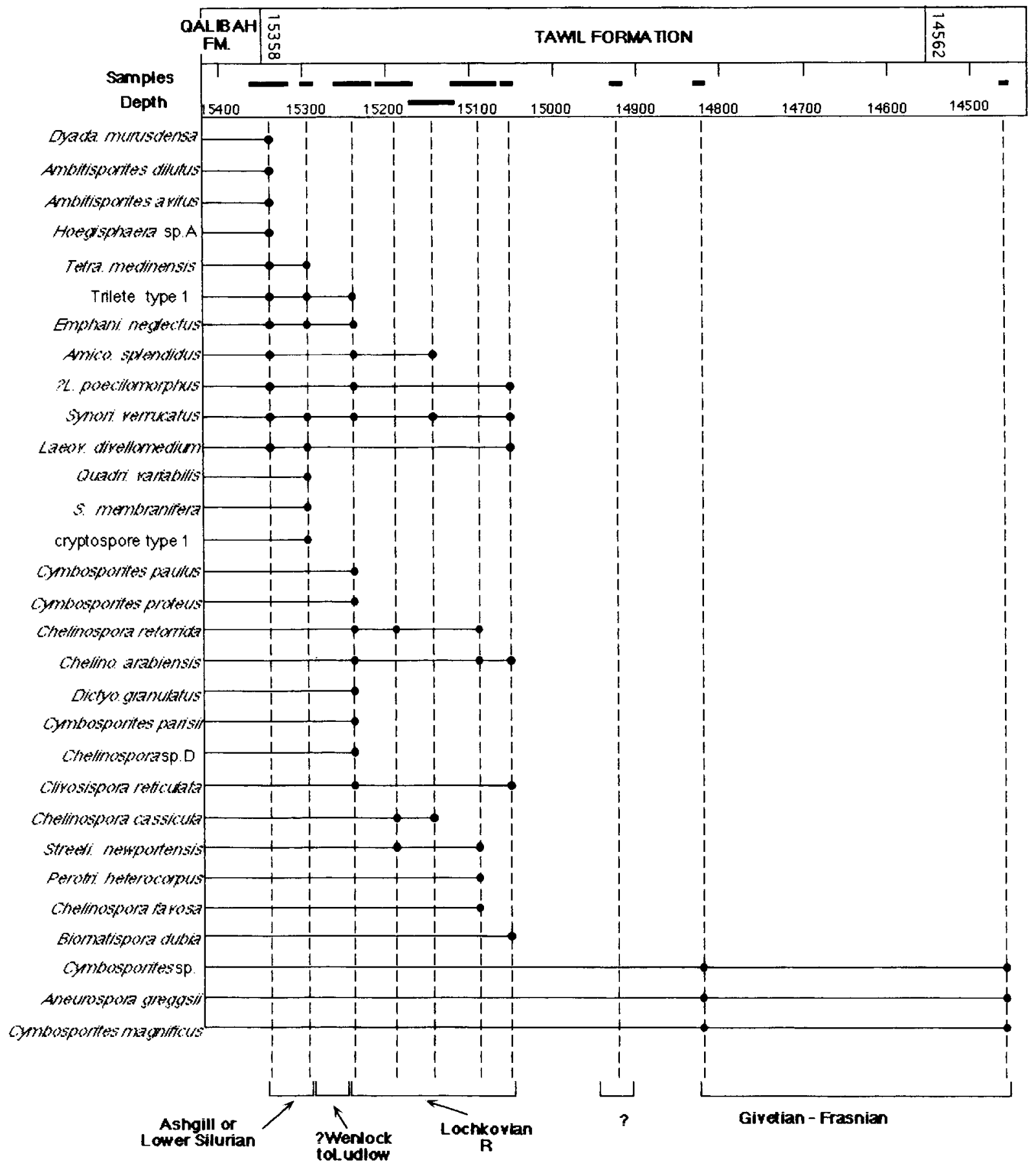

Fig. 3. Stratigraphic distributions of some selected spores in well UDYN-1. 
below). Amicosporites splendidus, Dictyotriletes granulatus, Cymbosporites parisii, Emphanisporites neglectus, Chelinospora sp. D (in Steemans, 1989), and Clivosispora reticulata have also been observed.

In the interval $15170-15210 \mathrm{ft}, 15120-15170 \mathrm{ft}$ and 15070-15120 ft from the lower part of the Tawil Formation, Streelispora newportensis, one of the MN Biozone index species, has been identified, together with numerous other characteristic miospores from the $\mathrm{R}$ Biozone. The interval $15070-15120 \mathrm{ft}$ contains Perotrilites heterocorpus. This spore is only known from the $\mathrm{N}$ and $\mathrm{R}$ Interval Biozones in Ardenne and in Britain (Steemans, 1989). There is only one report of this species in younger strata (Upper Pragian), where it had probably been reworked. It is assumed that these four intervals probably belong to the $R$ Biozone and the strata between 15260 and 15070 $\mathrm{ft}$ are therefore tentatively assigned to the lower part of the Lochkovian.

The interval $15050-15060 \mathrm{ft}$ contains on one hand Synorisporites verrucatus, the vertical extension of which does not exceed the MN Assemblage Biozone (Steemans, 1989) and, on the other hand, Biornatispora dubia, with its first occurrence in the BZ Assemblage Biozone. The vertical extensions of these two spore species are thus inconsistent. Some other species, e.g. Laeovancis divellomedium, Clivosispora reticulata, ?Lophozonotriletes poecilomorphus, show strong affinities with the Lochkovian MN Biozone. Thus, we conclude that this interval belongs, as the four previously described, to the $\mathrm{R}$ Interval Biozone, and is contaminated by post-R caved material.

The intervals $14820-14830 \mathrm{ft}$, from the middle and upper part of the Tawil Formation, and 14460 $\mathrm{ft}$, from the Jauf Formation, mainly contain very large specimens $(50-80 \mu \mathrm{m}$ in diameter) including Aneurospora greggsii and Cymbosporites magnificus. These two intervals can be assigned to the Givetian-Frasnian.

\subsection{Well TRBH-1}

The samples analysed here are obtained from cuttings in the intervals $3701-3753 \mathrm{ft}$ and
3806-3832 ft from the Sharawra member of the Qalibah Formation. These two intervals have yielded numerous acritarchs, but some chitinizoans have also been observed (Ancyrochitina sp., Angochitina thadeui, Clatrochitina sp. and Sphaerochitina pistiliformis; Verniers, pers. commun., 1992). About 50 spore specimens have been identified and these show Silurian and/or Lower Devonian affinities. Together with these spores, some cryptospores have been identified (Tetrahedraletes medinensis). A Silurian age is therefore assumed for these two intervals.

The overlying intervals, which belong to the lower part of the Tawil Formation, have been examined by Loboziak and Streel (1995-this issue); samples of the interval $3596-3622 \mathrm{ft}$ are determined to be Emsian in age (AB Assemblage Biozone).

\section{Biostratigraphy and palaeogeographic implications}

Results obtained from the three wells prove that it is possible to use the biozonation established in Ardenno-Rhenan type outcrops in the Gondwanan area. These results show that the Biozone $\mathrm{R}$, recognised in the well UDYN-1, where Chelinospora arabiensis Steemans, sp. nov. is first described, is not penetrated by the well DMMM-45, where Cymbosporites dammamensis Steemans, sp. nov. is defined. This last species is not found in well UDYN-1. The two new species seem to have at least a local biostratigraphic value. The absence of $C$. arabiensis in well DMMM-45 and of $C$. dammamensis in well UDYN-1 may indicate that the Lower Devonian strata are indeed of different age in the two wells, tentatively based on the Ardenno-Rhenan biozonation (Fig. 4).

In the three analysed wells, the Lower Devonian strata are unconformably situated on the Silurian (Fig. 1). The magnitude of missing beds increases in a SE-NW direction. The first Devonian levels in well UDYN-1 belong to the R Interval Biozone (lower part of the Lochkovian), in well DMMM-45 they range from the Si Biozone to the Z Biozone (upper part of the Lochkovian), whilst 
DMMM-45

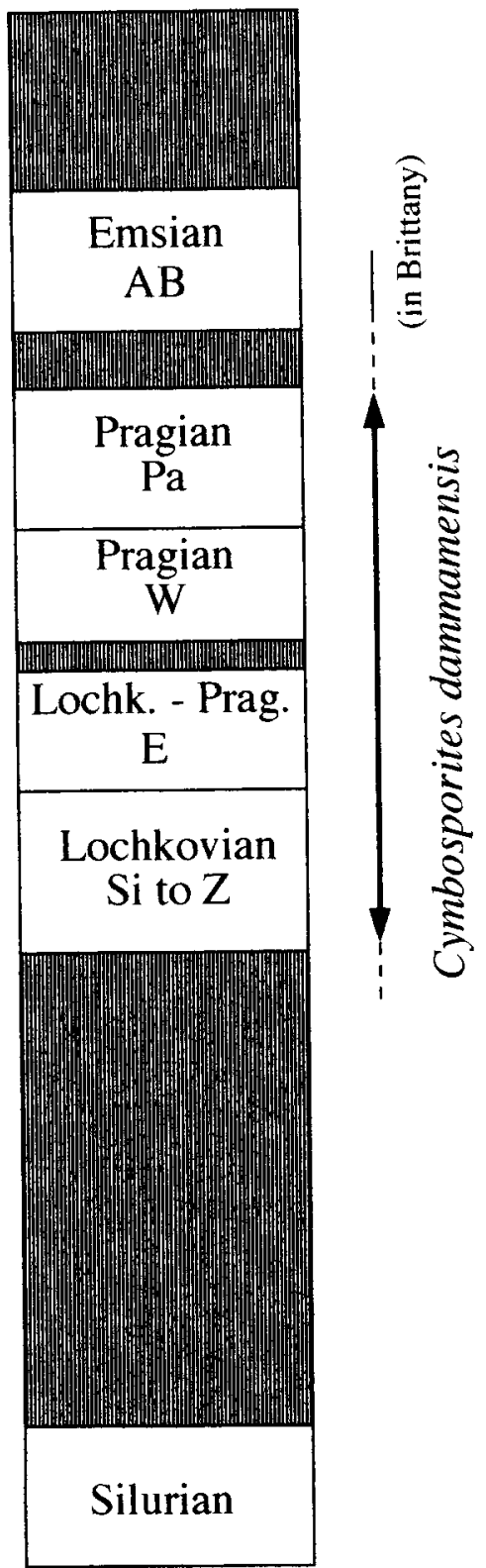

UDYN-1

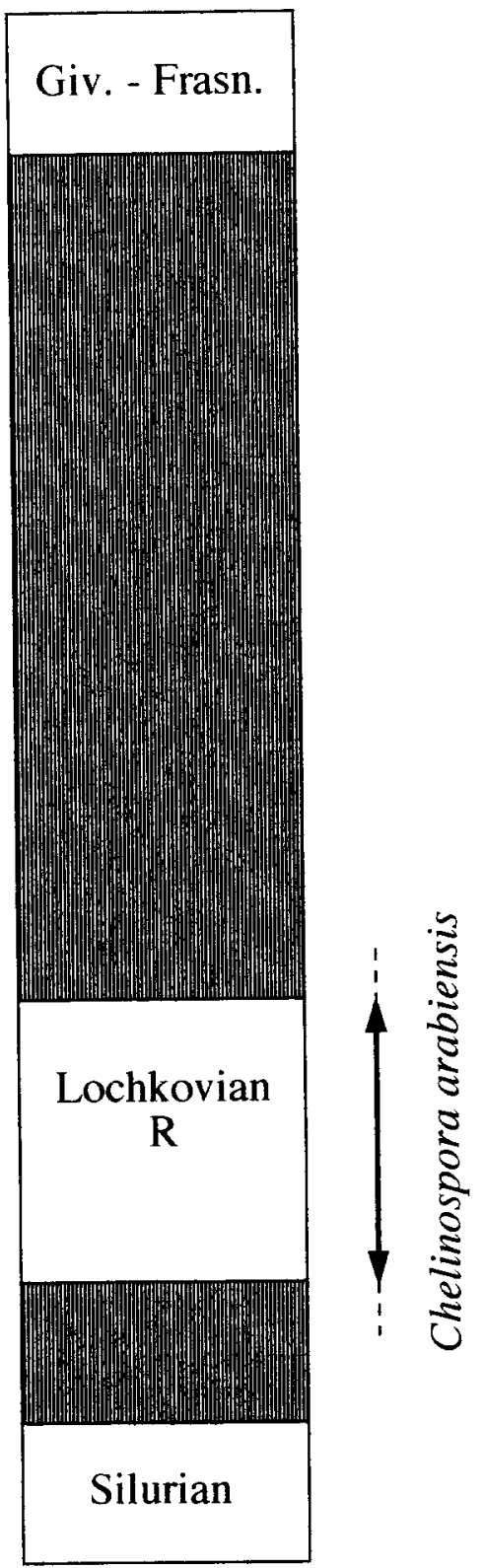

Fig. 4. Biostratigraphic distributions of the two new taxa in wells UDYN-1 and QMMM-45.

in well TRBH-1 they are indicative of the AB Assemblage Biozone (Early Emsian). These biostratigraphic data may suggest a Devonian transgression on the Silurian tectonised continent in an approximate SE-NW direction. The abovementioned hiatus is part of an unconformity and can be followed from central Saudi Arabia through Egypt, Libya, North Africa to Ghana, across to 
PLATE I
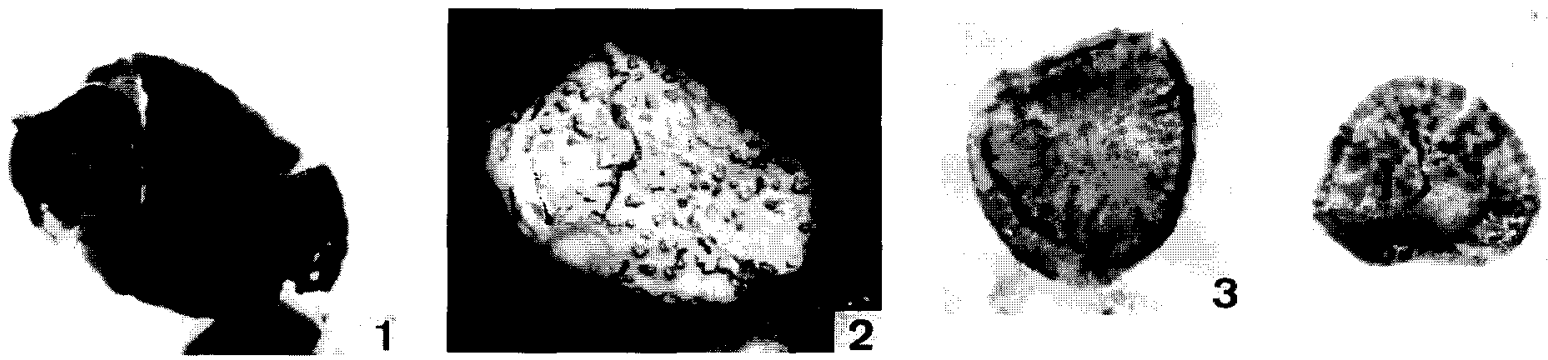

4
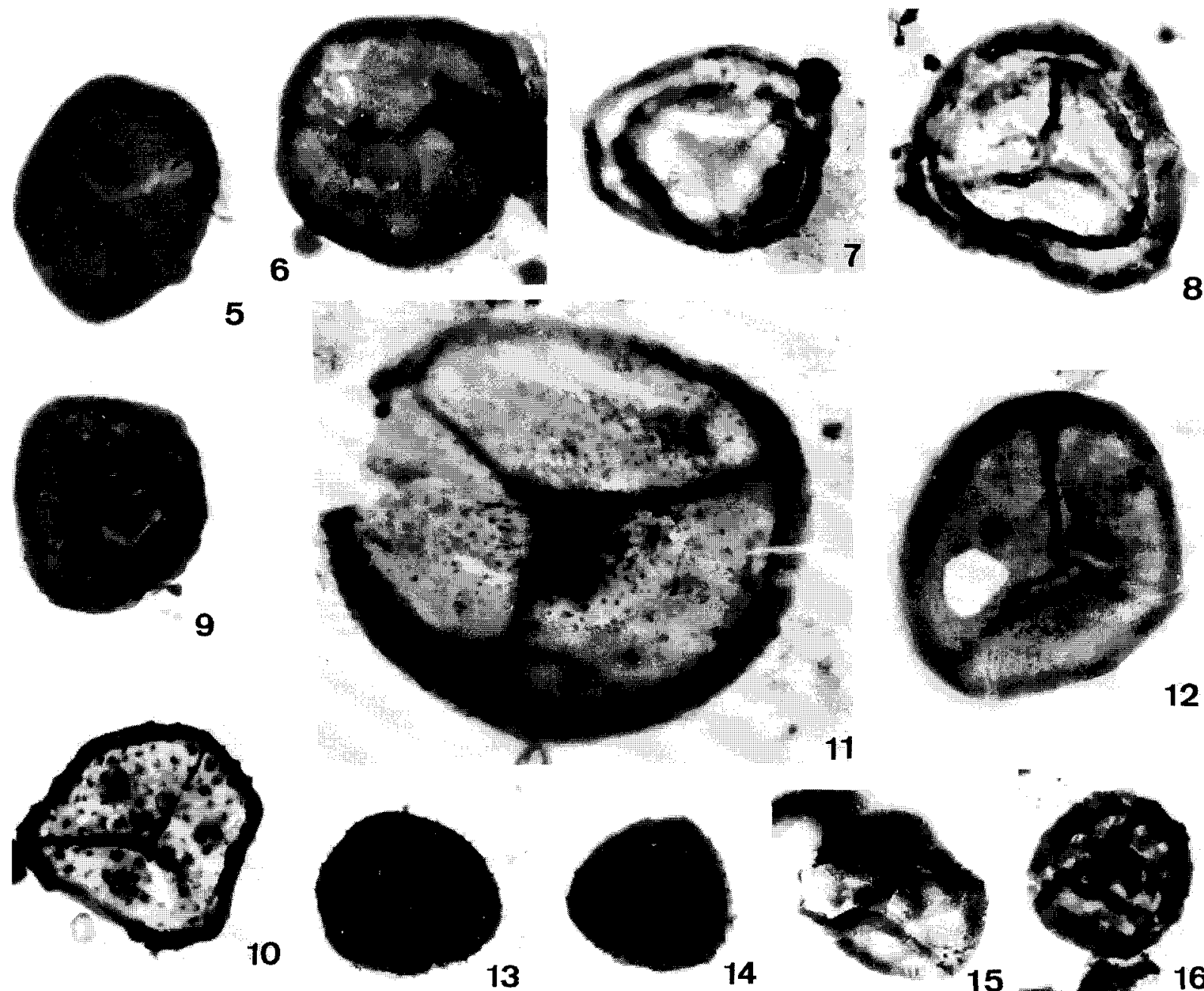

12
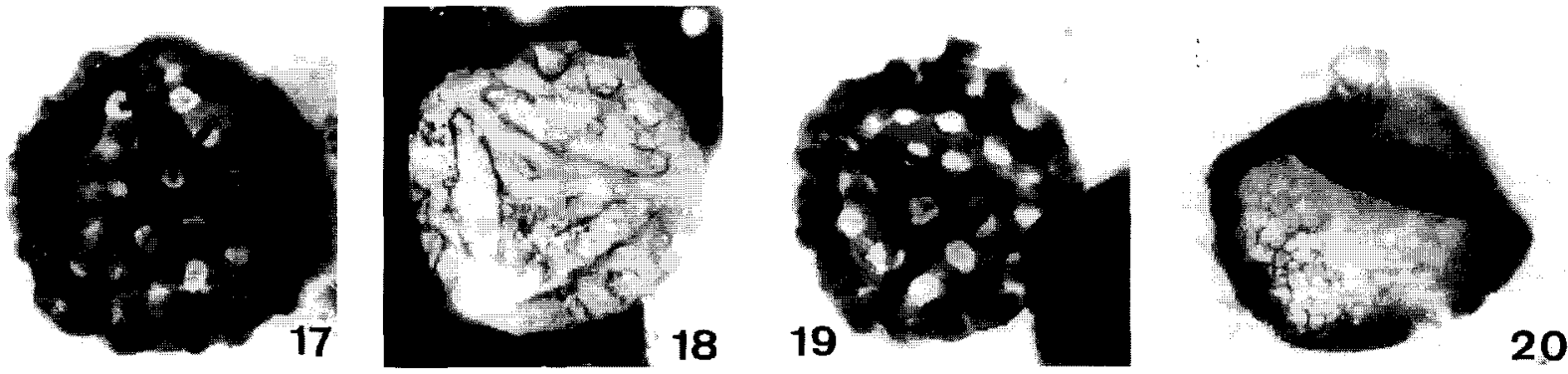
Brazil in South America, where it extends in a SW direction (Boucot, 1985; Gray, 1985).

\section{Systematics}

Two new species which could have biostratigraphic and palaeogeographic implications are described here. All the other listed species, some of which are illustrated here, have already been fully described elsewhere and therefore do not need further descriptions.

Genus Chelinospora Allen, 1965

Type: Chelinospora concinna Allen, 1965.

Chelinospora arabiensis Steemans, sp. nov. (Plate I, 16-19)

Holotype: UDYN-1 Well-1, sample at 15070-15120 $\mathrm{ft}$, reference slide coordinate: $\mathrm{V} 44$.

Stratigraphic occurrence: Due to the extensive caving, the present stratigraphic range may have to be revised. The specimens were only found in sediments of the MN Assemblage Biozone (Interval Biozone R) (Lochkovian) of well UDYN-1.

Diagnosis: Trilete circular miospore. Distal surface and proximo-equatorial margin are thickened by a patina. The patina shows an enlargement in the interrradial zone, giving a triangular outline to the contact area surface. Trilete mark reaches the internal margin of the patina and is bordered by three thick ribs delimiting a triangular area with thickened concave sides ( $2-3 \mu \mathrm{m}$ wide). The patina is foveolate on its entire surface. Foveae are subcircular, $2-3 \mu \mathrm{m}$ in diameter and regularly separated by muri $1-3 \mu \mathrm{m}$ wide. These foveae seen at the equatorial margin are U-shaped, 1-2 $\mu \mathrm{m}$ deep; 10-20 foveae are visible at the equatorial margin. Diameter: Equatorial diameter 23-34 $\mu \mathrm{m}$ (average: $30 \mu \mathrm{m}), 3$ specimens measured.

Comparison: The nature of the proximal surface distinguishes it from all other species of Chelinospora.

Genus Cymbosporites Allen, 1965

Type: Cymbosporites cyathus Allen, 1965.

\section{PLATE I}

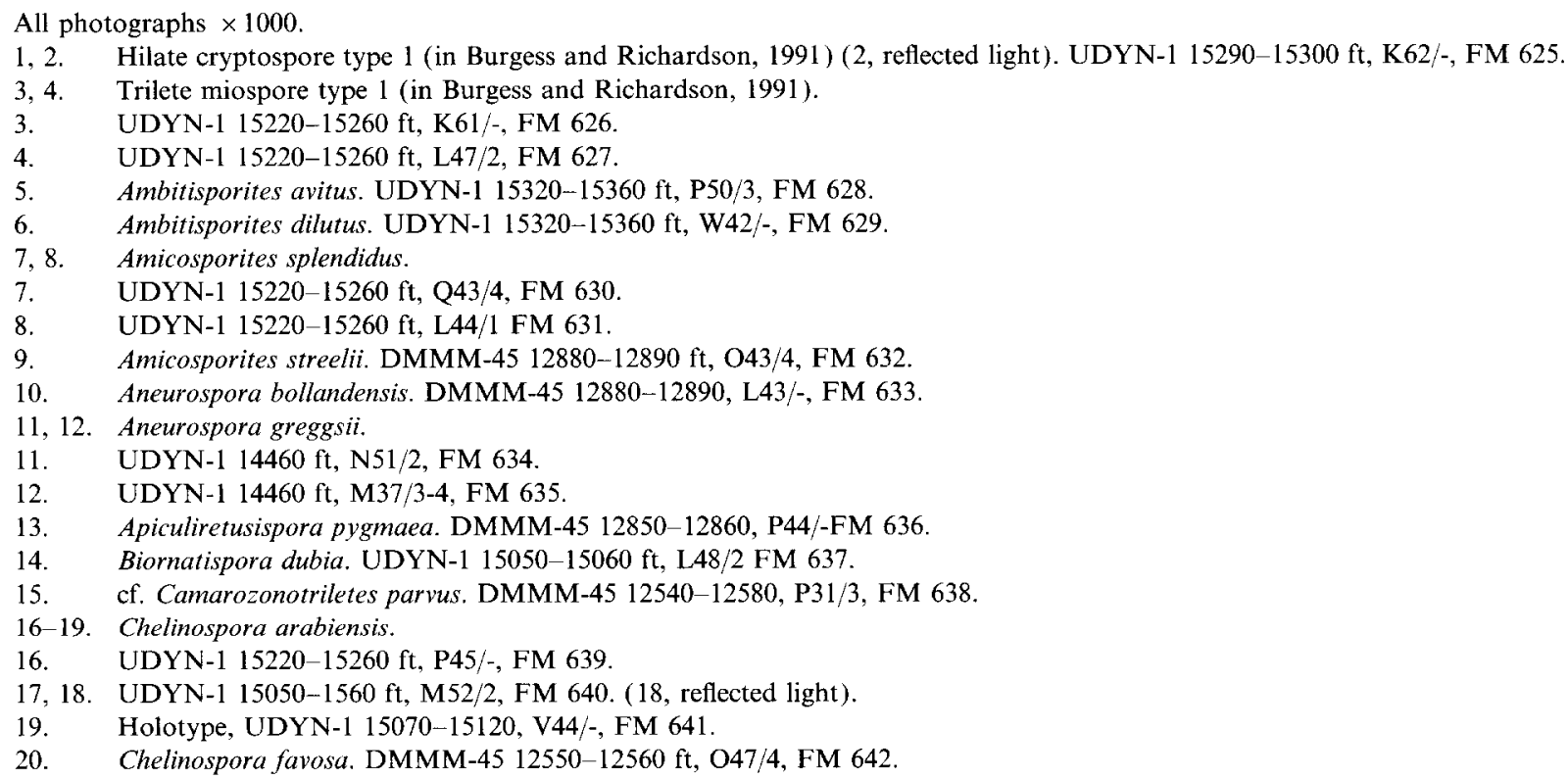


PLATE II
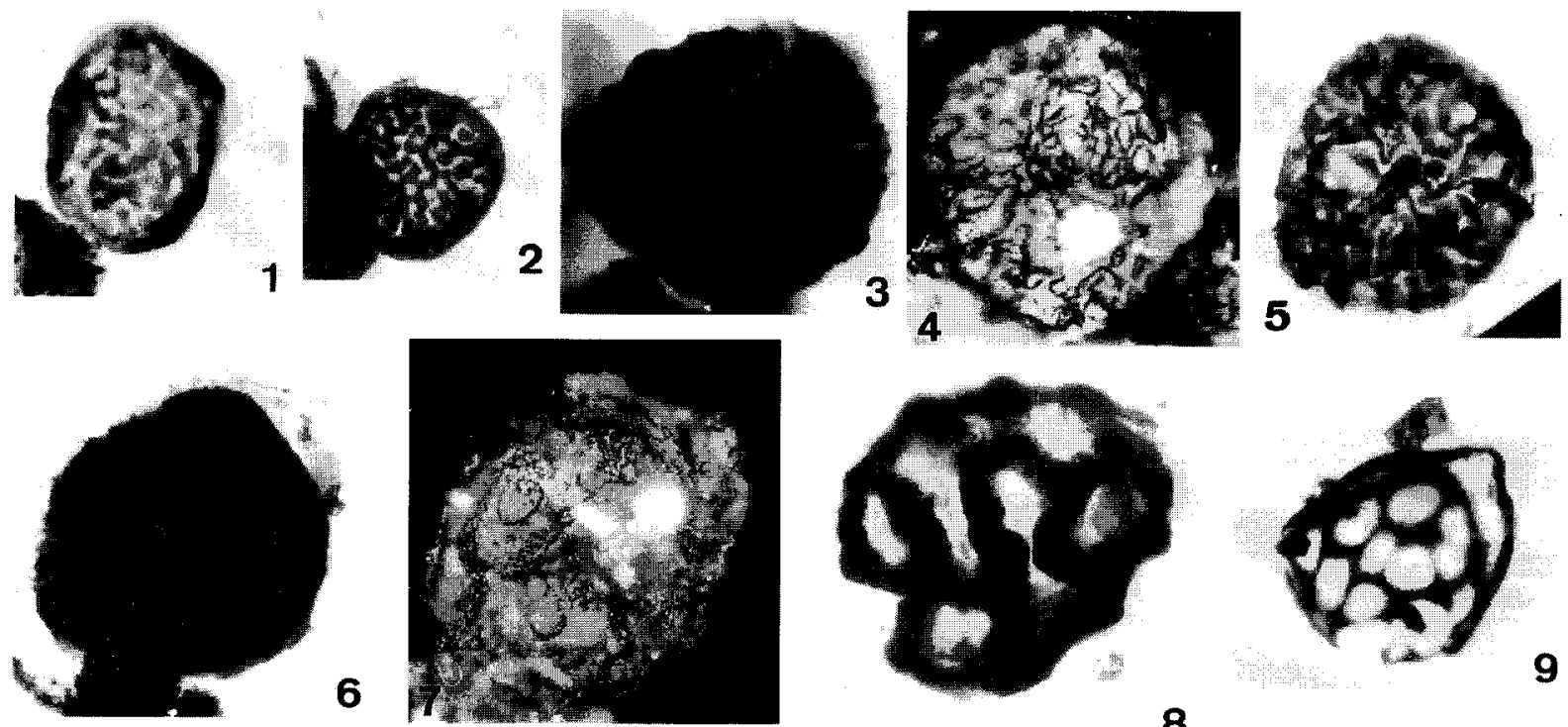

9
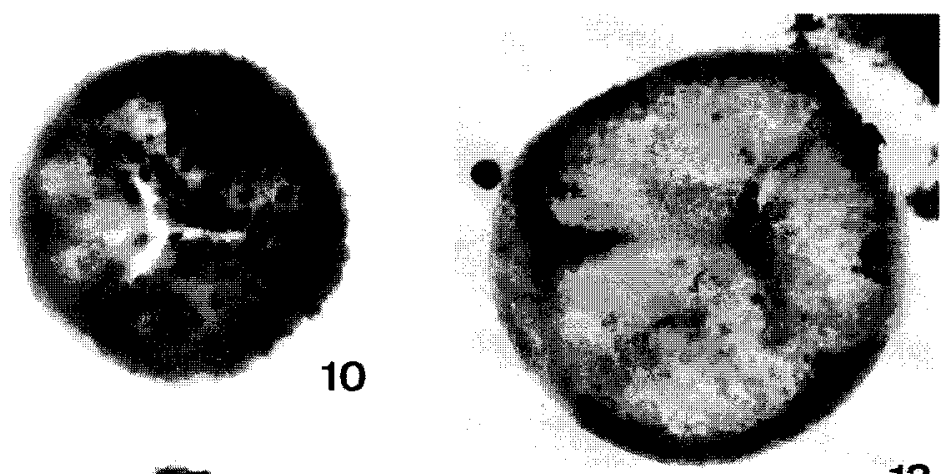

13
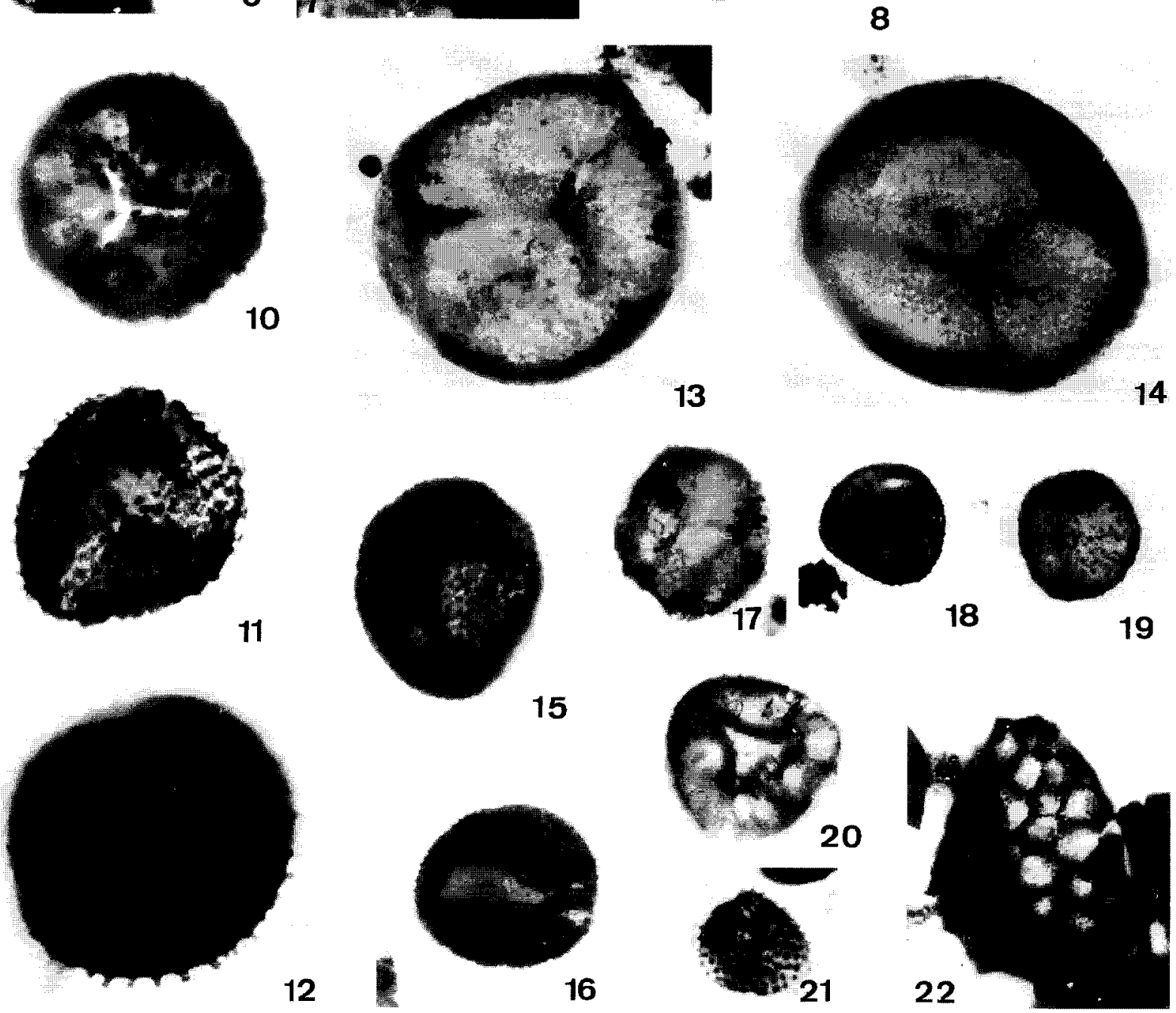
Cymbosporites dammamensis Steemans, sp. nov.

(Plate II, 10-12)

1983 Raistrickia sp. A-Le Hérissé, pp. 24-25, pl. 4, figs. 2, 8a,b.

1983 Raistrickia sp. B-Le Hérissé, p. 25, pl. 4, fig. 3.

1983 Raistrickia sp. D-Le Hérissé, p. 25, pl. 4, figs. 6, 7.

?1973 Raistrickia sp.-McGregor, pp. 35-36, pl. 4, figs. 9, 10.

Holotype: Well DMMM-45, sample at 12550 $12560 \mathrm{ft}$, reference slide coordinate: X65/2.

Stratigraphic occurrence: Due to the extensive caving, the present stratigraphic range may have to be revised. The specimens were observed in sediments of the MN Assemblage Biozone (Phylozone Si) (Lochkovian) to the PoW Assemblage Biozone (Interval Biozone Pa?) (Pragian) of well DMMM-45.

Le Hérissé found this species in Britain in his Assemblages 2 and 3 (Pragian and Emsian).

Diagnosis: Trilete circular miospore. Proximal face very smooth, frequently collapsed. Trilete mark very fine, generally observable as a slit with a " $Y$ " shape. Distal face is thickest, $1-3 \mu \mathrm{m}$ thick. The structure is a patina, ornamented by bacula and pila. Pila may have concave sides. The upper part of the pila are one to two times thicker than the lower part. The top is flat or concave, with occasionally bifurcate shape. The ornaments are regular, $1-2 \mu \mathrm{m}$ wide and high, $1-3 \mu \mathrm{m}$ apart.

Diameter: Equatorial diameter 29-43 $\mu \mathrm{m}$ (average: $34 \mu \mathrm{m}) 10$ specimens measured.

Comparison: The different specimens described by Le Hérissé (1983) are very similar to the specimens observed here. The ornamentation of Raistrickia sp. (in McGregor, 1973) is similar but there is no description of the thickness of the exine.

\section{Conclusions}

This study has proved that it is possible to use the Lower Devonian biozonation established in

\section{PLATE II}

All photographs $\times 1000$.

1,2. Chelinospora retorrida.

1. UDYN-1 15220-15260 ft, R50/1, FM 643.

2. UDYN-1 15170-15210 ft, J56/2, FM 644

3-5. Chelinospora sp. D (in Steemans, 1989).

3, 4. UDYN-1 15220-15260 ft, G49/3, FM 645. (4, reflected light).

5. UDYN-1 $15220-15260 \mathrm{ft}, \mathrm{T} 46 /-$, FM 646.

6, 7. Cirratriradites diaphanus. DMMM-45 12550-12560 ft, J41/2, FM 647. (7, reflected light).

8, 9. Clivosispora reticulata.

8. UDYN-1 $15170-15210 \mathrm{ft}, \mathrm{J} 59 / 4$, FM 648.

9. UDYN-1 15220-15260 ft, G61/1, FM 649.

10-12. Cymbosporites dammamensis.

10. Holotype, DMMM-45 $12550-12560 \mathrm{ft}$, slide 12-2, X65/2, FM 650.

11. DMMM-45 12550-12560 ft, slide 12-2, V37/1, FM 651.

12. DMMM-45 12900-12940 ft, slide 17559, O37/4, FM 652.

13, 14. Cymbosporites magnificus.

13. UDYN-1 $14460 \mathrm{ft}, \mathrm{L} 43 / 4$, FM 653.

14. UDYN-1 $14460 \mathrm{ft}, \mathrm{U} 43 / 2$, FM 654.

15, 16. Cymbosporites parisii.

15. UDYN-1 15070-15120 ft, G56/1, FM 655.

16. UDYN-1 15070-15120 ft, W46/3, FM 656.

17. Cymbosporites paulus. DMMM-45 12540-12580 ft, U25/2, FM 657 .

18, 19. Cymbosporites proteus.

18. DMMM-45 12850-12860 ft, L42/-, FM 658.

19. DMMM-45 $12900-12940 \mathrm{ft}$, slide 17559 , X48/4, FM 659.

20. Dibolisporites wetteldorfensis. DMMM-45 12540-12580 ft, X30/1, FM 660 .

21. Dibolisporites sp. E (in Steemans, 1989). DMMM-45 12880-12890 ft, Q46/-, FM 661. 

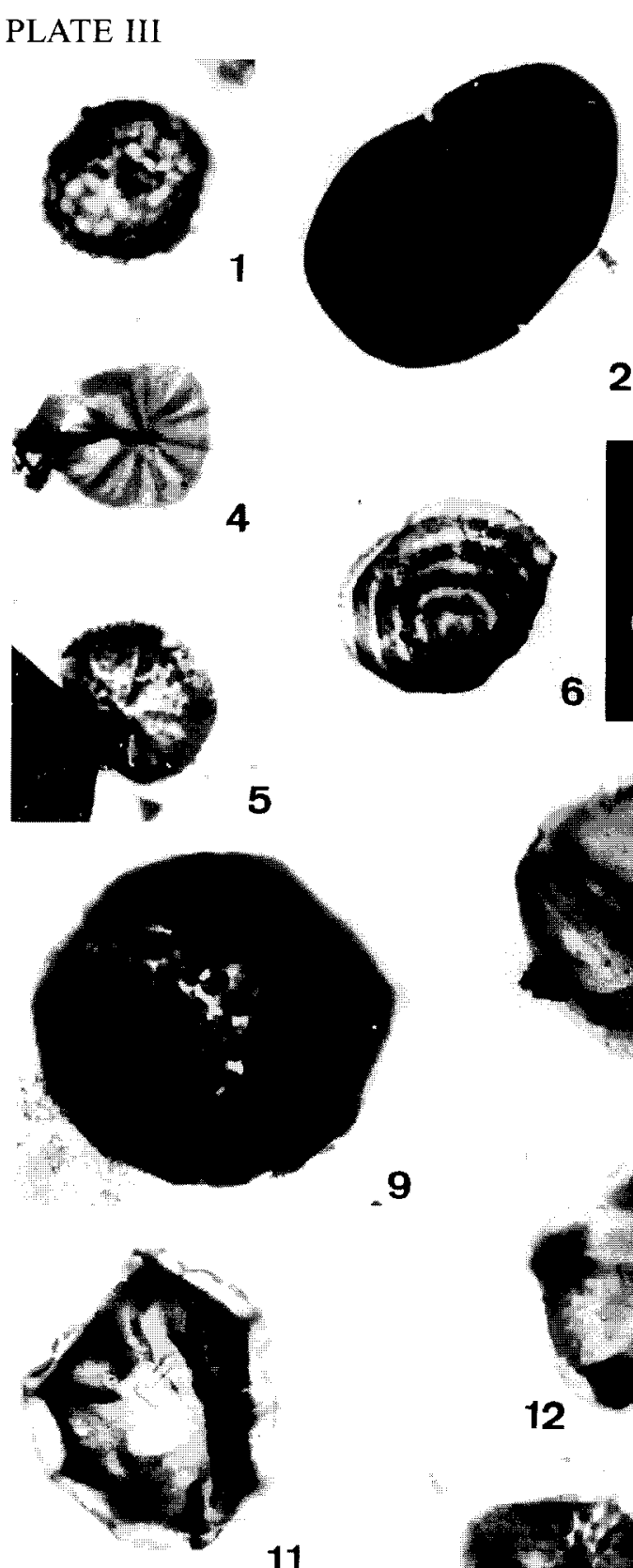

11
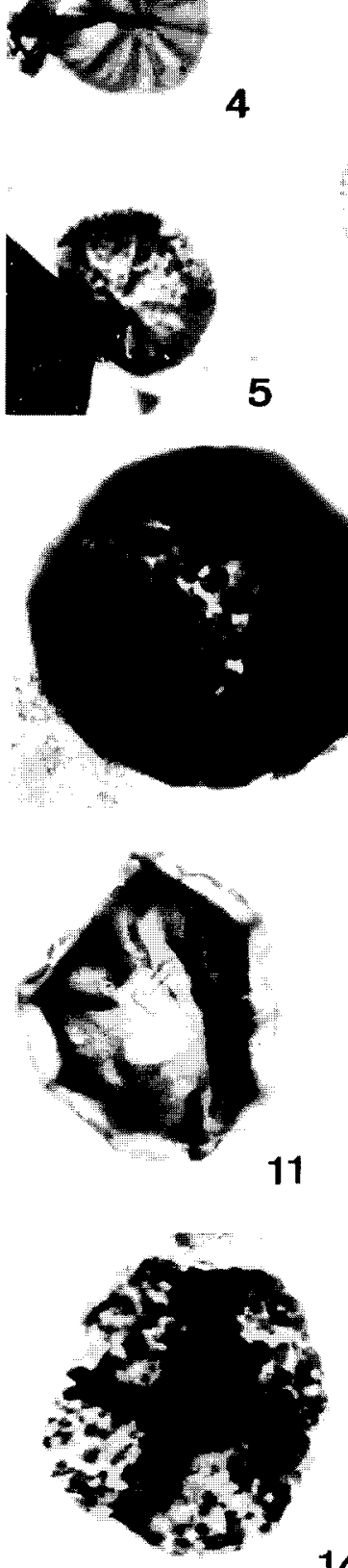

4

9

12
2
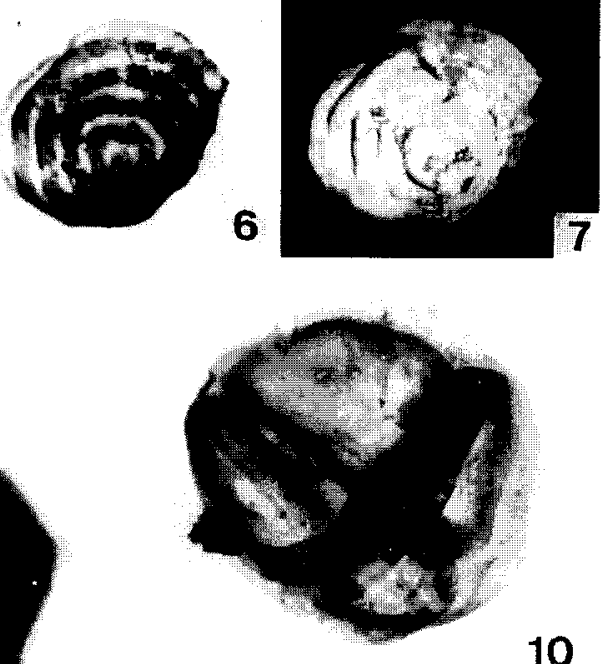

10
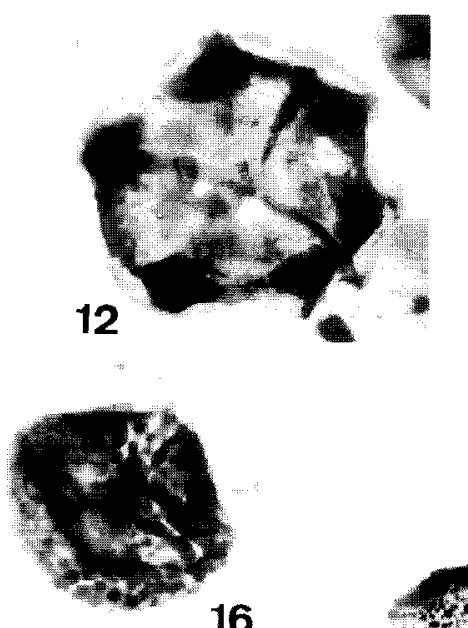

16

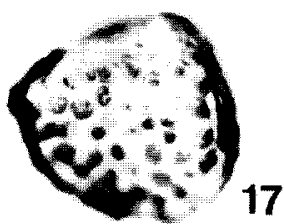

3

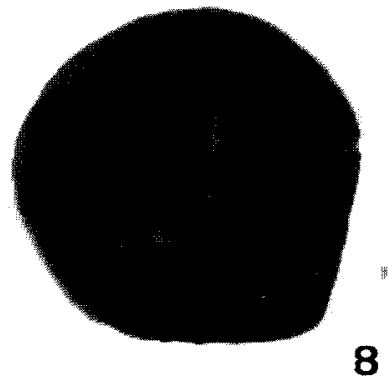

8
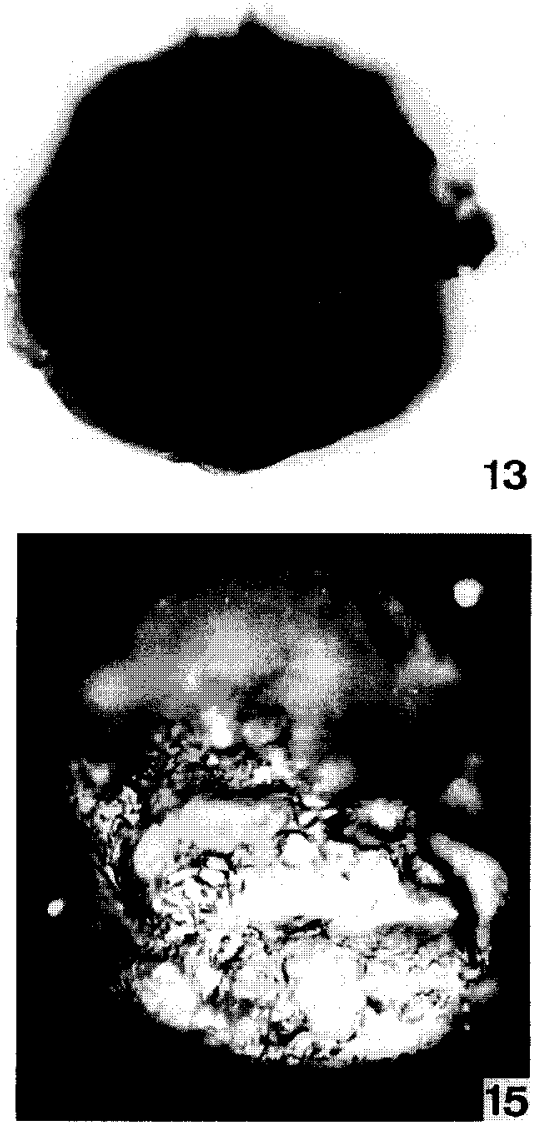

19

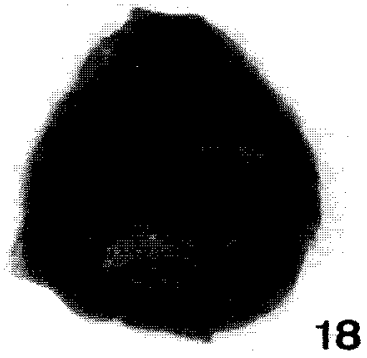


Europe for the Gondwanan region. The same succession of first occurrences of the characteristic species is recognised. Two new species are described which may have biostratigraphic value. The biostratigraphic data obtained suggest a Devonian transgression on the Silurian continent in an approximate $\mathrm{SE}-\mathrm{NW}$ direction.

\section{Appendix 1. List of species}

Hilate cryptospore type 1, in Burgess and Richardson, 1991 Trilete miospore type 1, in Burgess and Richardson, 1991 Ambitisporites avitus Hoffmeister, 1959

Ambitisporites (Punctatisporites) dilutus (Hoffmeister)

Richardson and Lister, 1969

Amicosporites splendidus Cramer, 1967

Amicosporites streelii Steemans, 1989

Aneurospora bollandensis Steemans, 1989

Aneurospora greggsii (McGregor) Streel, in Becker et al., 1974 Apiculiretusispora pygmaea McGregor, 1973

Biornatispora (Camptotriletes) dubia (McGregor) Steemans, 1989

cf. Camarozonotriletes parvus Owens, 1971

Camarozonotriletes sextantii McGregor and Camfield, 1976

Chelinospora arabiensis Steemans, sp. nov.

Chelinospora (Dictyotriletes) favosa (McGregor and Camfield)

Steemans, 1989

Chelinospora retorrida Turnau, 1986

Chelinospora sp. D in Steemans, 1989
Cirratriradites diaphanus Steemans, 1989

Clivosispora reticulata Rodriguez, 1978

Cymbosporites dammamensis Steemans, sp. nov.

Cymbosporites magnificus McGregor and Camfield, 1982

Cymbosporites parisii Steemans, 1989

Cymbosporites paulus McGregor and Camfield, 1976

Cymbosporites proteus McGregor and Camfield, 1976

Dibolisporites wetteldorfensis Lanninger, 1968

Dibolisporites sp. E, in Steemans, 1989

Dictyotriletes (Reticulatisporites) emsiensis (Allen) McGregor, 1973

Dictyotriletes granulatus Steemans, 1989

Dyadospora murusdensa Strother and Traverse, 1979

Emphanisporites micrornatus Richardson and Lister var. micrornatus Steemans and Gerrienne, 1984

Emphanisporites micrornatus Richardson and Lister var. sinuosus Steemans and Gerrienne, 1984

Emphanisporites neglectus Vigran, 1964

Emphanisporites novellus McGregor and Camfield, 1976

Hoegisphaera sp. A, in Gao and Ye, 1987

Laeovancis (Archaeozonotriletes) divellomedium (Chibrikova) Burgess and Richardson, 1991

Lophozonotriletes? poecilomorphus Richardson and Ioannides, 1973

Perotrilites heterocorpus Steemans, 1989

Quadrisporites (Tetrasporites) variabilis (Cramer) Strother, 1991

Segestrespora (Dyadospora) membranifera (Johnson) Burgess, 1991

Segestrespora (Pseudodyadospora) $\quad$ sp. $\quad$ B (Richardson) Steemans, unpubl. data

Synorisporites verrucatus Richardson and Lister, 1969

Tetrahedraletes medinensis Strother and Traverse, 1979

Verrucosisporites polygonalis Lanninger, 1968

\section{PLATE III}

All photographs $\times 1000$.

1. Dictyotriletes granulatus. UDYN-1 $15220-15260 \mathrm{ft}, \mathrm{N} 45 / 1-2$, FM 662.

2. Dyadospora murusdensa. UDYN-1 $15320-15360 \mathrm{ft}, \mathrm{T} 51 / 1-3$, FM 663.

3. ?Emphanisporites micrornatus var. sinuosus. UDYN-1 12940-13000 ft, Q63/1, 664 .

4. $\quad$ Emphanisporites neglectus. UDYN-1 15070-15120 ft, G57/4, FM 665.

5. Emphanisporites novellus. DMMM-45 12880-12890 ft, M61/4, FM 666.

6, 7. Hoegisphaera sp. A (in Gao, 1987). UDYN-1 15320-15360 ft, P58/-, FM 667. (7, reflected light).

8. Laeovancis divellomedium. UDYN-1 15290-15300 ft, H52/1, FM 668.

9. Lophozonotriletes? poecilomorphus. UDYN-1 15320-15360 ft, X52/2, FM 669.

10. Tetrahedraletes medinensis UDYN-1 $15320-15360 \mathrm{ft}, \mathrm{N} 45 / 2$, FM 670.

11, 12. Perotrilites heterocorpus.

11. UDYN-1 15070-15120 ft, U60/1, FM 671.

12. UDYN-1 15070-15120 ft, T57/2, FM 672.

13. Perotrilites reticulatus. DMMM-45 $12900-12940 \mathrm{ft}$, F56/4, FM 673.

14. Quadrisporites variabilis. UDYN-1 $15290-15300 \mathrm{ft}, \mathrm{R} 39 /-$, FM 674.

15. Segestrespora membranifera. Reflected light, UDYN-1 15290-15300 ft, T61/3, FM 675 .

16. Streelispora newportensis. UDYN-1 15070-15120 ft, J47/3, FM 676.

17. Synorisporites verrucatus. UDYN-1 $15320-15360 \mathrm{ft}, \mathrm{Y} 42 / 2$, FM 677.

18. Tetrahedraletes medinensis. UDYN-1 $15320-15360 \mathrm{ft}, \mathrm{M} 46 / 4$, FM 678.

19. Verrucosisporites polygonalis. DMMM-45 12550-12560 ft, F41/-, FM 679 


\section{References}

Allen, K.C., 1965. Lower to Middle Devonian spores of North and Central Vestspitsbergen. Palaeontology, 8(4): 687-748.

Boucot, A., 1985. Late Silurian-early Devonian biogeography provincialism, evolution and extinction. Philos. Trans. R. Soc. London B, 309: 323-339.

Burgess, N.D., 1991. Silurian cryptospores and miospores from the type Llandovery area, south-west Wales. Palaeontology, 34(3): 575-599.

Burgess, N.D. and Richardson, J.B., 1991. Silurian cryptospores and miospores from the type Wenlock area, Shropshire, England. Palaeontology, 34(3): 601-628.

Cramer, F., 1967. Palynology of Silurian and Devonian rocks in Northwest Spain. Bol. Inst. Geol. Esp., 77: 225-286.

Gao, L. and Ye, X., 1987. Late Silurian and Devonian spores from West Qinling Mountains. In: Late Silurian-Devonian strata and fossils from Luqu-Tewo area of west Qinling Mountains, China, 2, pp. 379-450.

Gray, J., 1985. The microfossil record of early land plants; advances in understanding of early terrestrialization, 1970-1984. In: W.G. Chaloner and J.D. Lawson (Editor), Evolution and Environment in the Late Silurian and Early Devonian. Philos. Trans. R. Soc. London B, 309: 167-195.

Le Hérissé, A., 1983. Les spores du Dévonien inférieur du Synclinorium de Laval (Massif Armoricain). Palaeontographica B, 188: 1-81.

Loboziak, S. and Streel, M., 1995. Late Lower and Middle
Devonian miospores from Saudi Arabia. Rev. Paiaeobot. Palynol., 89: 105-113, this issue.

Richardson, J.B., 1988. Late Ordovician and Early Silurian cryptospores and miospores from Northeast Libya. In: A. El-Arnauti, B. Owens and B. Thusu (Editors), Subsurface Palynostratigraphy of Northeast Libya. Garyounis Univ. Publ., Benghazi, pp. 89-109.

Richardson, J.B. and McGregor, D.C., 1986. Silurian and Devonian spore zones of the Old Red Sandstone continent and adjacent regions. Geol. Surv. Can. Bull., 364: 1-79.

Richardson, J.B., Ford, J.H. and Parker, F., 1984. Miospores, correlation and age of some Scottish Lower Old Red Sandstone sediments from the Strathmore region (Fife and Angus). J. Micropalaeontol., 3(2): 109-124.

Steemans, P., 1989. Palynostratigraphie de l'Eodévonien dans l'ouest de l'Europe. Prof. Pap. Mém. Explor. Cart. Géol. Min. Belg., 27: 1-453.

Streel, M., Higgs, K., Loboziak, S., Riegel, W. and Steemans, P., 1987. Spore stratigraphy and correlation with faunas and floras in the type marine Devonian of the Ardenno-Rhenish regions. Rev. Palaeobot. Palynol., 50: 211-229.

Streel, M., Loboziak, S. and Steemans, P., 1991. SilurianDevonian miospores. A preliminary report. In: Palaeozoic Palynostratigraphy Project, Kingdom of Saudi Arabia. C.R. Saudi Aramco/CIMP Workshop, Brest, France, Novembre 1991.

Turnau, E., 1986. Lower to Middle Devonian spores from the Vicinity of Pionki (Central Poland). Rev. Palaeobot. Palynol., 46: 311-354. 